\title{
Pengaruh Pemberian Pupuk Kompos Berbahan Dasar Guano dengan Level Berbeda terhadap Pertumbuhan Turi (Sesbania grandiflora)
}

\author{
Felix Bukifan ${ }^{\mathrm{a}}$, Stefanus Sio ${ }^{\mathrm{b}}$, Gerson F. Bira ${ }^{\mathrm{c}}$ \\ ${ }^{a}$ Fakultas Pertanian, Universitas Timor, Kefamenanu, TTU - NTT, Indonesia, email: felixbukifan92@gmail.com \\ ${ }^{b}$ Fakultas Pertanian, Universitas Timor, Kefamenanu, TTU - NTT, Indonesia, email: Stefsio67@ gmail.com \\ cFakultas Pertanian, Universitas Timor, Kefamenanu, TTU - NTT, Indonesia, email: Gersonbira@yahoo.co.id
}

\section{Article Info}

\section{Article history:}

Received 18 Desember 2019

Received in revised form 7 Januari 2019

Accepted 28 Januaril 2019

DOI:

https://doi.org/10.32938/ja.v3i1.643

\section{Keywords:}

Kompos

Guano

Turi

\begin{abstract}
Abstrak
Tujuan dari penelitian ini untuk mengetahui pengaruh pemberian pupuk kompos berbahan dasar guano dengan level yang berbeda terhadap pertumbuhan turi (Sesbania grandiflora). Alat yang digunakan terdiri dari: peralatan ukur seperti mister, meteran, jangka sorong, oven, timbangan duduk (digital); peralatan bercocok tanam seperti parang, ember, linggis, pacul dan skop sedangkan bahannya terdiri dari bibit atau anakan turi sebanyak 128 anakan, kotoran kelelawar (guano) $100 \mathrm{~kg}$, jerami padi $10 \mathrm{~kg}$, dedak padi $6 \mathrm{~kg}$, gula $0,5 \mathrm{~kg}$, EM4 (Effective Microorganisms 4) $500 \mathrm{cc}$, terpal, karung dan air secukupnya. Rancangan yang digunakan dalam penelitian ini adalah Rancangan Acak Kelompok (RAK) dengan 4 perlakuan dan 4 ulangan sehingga terdapat 16 satuan percobaan. R0 = Tanpa pemberian kompos guano (kontrol), R1 = Pemberian pupuk kompos $200 \mathrm{~g} /$ lubang tanam, R2 = Pemberian pupuk kompos $500 \mathrm{~g} / \mathrm{lubang}$ tanam, R3 = Pemberian pupuk kompos $800 \mathrm{~g} /$ lubang tanam. Variabel pengamatan yaitu Tinggi tanaman, diameter batang, dan jumlah helai daun. Pengamatan dan pengambilan data dilakukan sebanyak 4 kali (14 HST, 21 HST, 28 HST dan 35 HST). Data yang diperoleh dianalisis dengan menggunakan analisis sidik ragam dan dilanjutkan dengan uji duncan untuk melihat perbedaan antara perlakuan. Hasil penelitian ini menunjukkan bahwa pemberian kompos guano pada level $800 \mathrm{~g}$ pada hari ke 35 HST secara signifikan meningkatkan tinggi tanaman yaitu sebesar $57,18 \mathrm{~cm}$ diameter batang $0,81 \mathrm{~mm}$ dan jumlah helai daun 16,00 helai. Disimpulkan bahwa pemberian pupuk kompos berbahan dasar guano sangat efektif dalam meningkatkan nilai kesuburan tanah sehingga dapat meningkatkan pertumbuhan dan produksi tanaman turi (Sesbania grandiflora) yang terlihat dari tinggi tanaman, diameter batang dan jumlah helai daun.
\end{abstract}

\section{Pendahuluan}

Kebutuhan hijauan makanan ternak merupakan faktor utama dalam peningkatan produktivitas ternak. Untuk itu perlu dibutuhkan manajemen yang tepat dalam pembudidayaannya sehingga dapat memenuhi kebutuhan nutrisi ternak baik jumlah, kualitas dan ketersediaannya. Salah satunya hijauan makanan ternak yang perlu dikembangkan adalah tanaman turi (Sesbania grandiflora). Turi merupakan tanaman leguminosa yang sangat potensial dimanfaatkan sebagai makanan ternak. Kandungan nutrisi yang dimiliki oleh tanaman turi sangat dibutuhkan oleh ternak dalam peningkatan produksi. Siregar (1994) menyatakan bahwa hasil analisis kadar protein kasar pada beberapa bahan pakan ternak, kaliandra (Caliandra calothyrsus), lamtoro (Leucaena leucepala), gamal (Gliricidia maculate), beberapa jenis rumput, rumput benggala dan rumput gajah tertingginya pada turi.

Untuk meningkatkan pertumbuhan turi (Sesbania grandiflora) maka diperlukan bahan lain untuk memacu pertumbuhannya, seperti pupuk. Pupuk adalah bahan yang diberikan ke dalam tanah baik yang organik maupun anorganik dengan maksud untuk mengganti kehilangan unsur hara dari dalam tanah dan bertujuan untuk meningkatkan produksi tanaman (Sutedjo, 2002). Untuk meningkatkan pembudidayaan perlu menerapkan sistem pertanian organik karna selain ramah lingkungan, biaya yang diperlukan untuk pengadaan pun relatif sedikit.

Menurut Setyorini (2006), kompos merupakan bahan organik seperti daun-daunan, jerami, alang-alang, rumput-rumputan, dedak padi, batang jagung, sulur, carang-carang serta kotoran hewan yang telah mengalami proses dekomposisi oleh mikroorganisme pengurai sehingga memperbaiki sifat-sifat tanah. Pupuk organik berbentuk padat atau cair yang dipergunakan untuk memperbaiki sifat fisik, kimia dan biologi tanah. Pupuk organik banyak mengandung bahan organik dari pada kadar haranya (Susanto, 2002). Salah satu jenis pupuk organik yang dapat dimanfaatkan yaitu kotoran kelelawar atau biasa disebut guano.

Pupuk guano adalah pupuk yang berasal dari kotoran kelelawar dan sudah mengendap lama di dalam gua dan telah tercampur dengan tanah dan bakteri pengurai. Kotoran kelelawar yang disebut pupuk guano ternyata memiliki potensi besar sebagai pupuk organik sebab guano kelelawar mengandung banyak unsur hara penting bagi tanaman yaitu: 8-13\% N; 5-12\% P;1,5-2\% K;7,5-11\% $\mathrm{Mg}$; dan 2-3,5\% S (Lingga dan Marsono, 2004). Dengan melihat kandungan unsur hara pada kotoran kelelawar maka perlu diolah sebagai pupuk padat dengan memanfaatkan bahan pengurai EM4 (Effective Microorganisms 4) yang berperan sebagai katalisator untuk mempercepat pengomposan dengan hasil dan mutu yang baik karena mengandung unsur-unsur hara yang diperlukan tanaman (Widowati et al., 2005). Dengan aplikasi pupuk guano diharapkan dapat meningkatkan pertumbuhan tanaman turi (Sesbania grandiflora).

\section{Metode}

Penelitian ini dilaksanakan di kebun percobaan Fakultas Pertanian Universitas Timor, Kelurahan Sasi, Kecamatan Kota Kefamenanu, Kabupaten Timor Tengah Utara selama 60 hari. Alat yang digunakan dalam penelitian ini terdiri dari: peralatan ukur seperti mistar, meteran, jangka sorong, oven, timbangan duduk (digital); peralatan bercocok tanam seperti parang, ember, linggis, pacul dan skop. Bahan yang digunakan dalam penelitian ini yaitu: bibit atau anakan turi sebanyak 128 anakan, kotoran kelelawar (guano) $100 \mathrm{~kg}$, jerami padi $10 \mathrm{~kg}$, dedak padi $6 \mathrm{~kg}$, gula 0,5 kg, EM4 (Effective Microorganisms 4) 500 cc, terpal, karung dan air secukupnya.

Metode yang digunakan dalam penelitian ini yaitu: metode eksperimen dan menggunakan Rancangan Acak Kelompok (RAK) dengan 4 perlakuan dan
4 ulangan sehingga terdapat 16 satuan percobaan yang diuji adalah sebagai berikut:

$\mathrm{R} 0$ = Tanpa pemberian pupuk kompos (kontrol)

$\mathrm{R} 1=$ Pemberian pupuk kompos $200 \mathrm{~g} / \mathrm{lubang}$ tanam .

$\mathrm{R} 2=$ Pemberian pupuk kompos $500 \mathrm{~g} / \mathrm{lubang}$ tanam

$\mathrm{R} 3=$ Pemberian pupuk kompos $800 \mathrm{~g} / \mathrm{lubang}$ tanam

Pembuatan kompos dilakukan dengan cara larutan EM4 dan gula dilarutkan ke dalam air, Disiramkan ke kotoran kelelawar, jerami padi (dicacah dengan ukuran $\pm 2 \mathrm{~cm}$ ) dan dedak padi kemudian dicampur hingga merata, Ditutup lalu didiamkan selama 21 hari dan sesering mungkin diukur suhunya, suhu ideal $40-50^{\circ} \mathrm{C}$ (Murbandono, 2000). Pemberian pupuk kompos dilakukan seminggu sesudah pengolahan tanah sesuai dosis perlakuan dan diinkubasi selama dua minggu dengan tujuan agar mengurangi aktivitas mikroorganisme yang terdapat pada pupuk kompos yang diberikan pada lubang tanam. Penanaman dilakukan 2 minggu setelah aplikasi pupuk kompos tepat pada lubang tanam yang telah disiapkan. Penyiraman dapat dilakukan 2 kali sehari yaitu pagi dan sore hari, penyulaman dilakukan bila ada tanaman yang mati atau tidak tumbuh dan pengendalian hama dan penyakit (bila terserang). Variabel yang dilihat adalah tinggi tanaman, diameter batang dan jumlah helai daun yang diambil sebanyak 4 kali (14 hari setelah tanam (HST), 21 HST, 28 HST dan 35 HST). Data yang diperoleh dianalisis dengan menggunakan analisis sidik ragam dan dilanjutkan dengan uji duncan untuk melihat perbedaan antara perlakuan menurut Steel and Torrie (1995).

\section{Hasil dan Pembahasan}

\subsection{Pengaruh Perlakuan terhadap Tinggi Tanaman Turi}

Tinggi tanaman merupakan salah satu parameter yang digunakan untuk mengukur pertumbuhan turi. Hasil pengukuran terhadap tinggi tanaman selama penelitian dapat dilihat pada Tabel 1 .

Hasil analisis sidik ragam menunjukkan kompos guano (800g) berpengaruh nyata terhadap variabel pengamatan tinggi tanaman 14 HST, 21 HST dan 35 HST dimana tanah yang diberikan kompos guano $(800 \mathrm{~g})$ cenderung meningkatkan tinggi tanaman 14 HST $(21,86 \mathrm{~cm}), 21$ HST $(31,04 \mathrm{~cm}), 28$ HST $(42,18 \mathrm{~cm})$ dan 35 HST $(57,18 \mathrm{~cm})$ dibandingkan tanaman turi yang diberikan kompos guano $200 \mathrm{~g}$, 500g dan kontrol. Hal ini disebabkan karena kandungan unsur hara yang tersedia pada pupuk kompos guano mampu mencukupi dan dapat memacu pertumbuhan tinggi tanaman turi. Kandungan unsur hara yang tersedia $\mathrm{N}(\mathrm{R} 1=451 \%, \mathrm{R} 2=1127,5 \%$ dan $\mathrm{R} 3=1804 \%)$. Tinggi tanaman yang lebih tinggi pada perlakuan dengan pemberian kompos guano $800 \mathrm{~g}$, karena pupuk kompos yang digunakan mengandung unsur hara terutama $\mathrm{N}$ yang dibutuhkan tanaman untuk pertumbuhan terutama pertumbuhan vegetatif Pemberian kompos guano dapat meningkatkan ketersediaan unsur hara $\mathrm{N}$ pada tanah sehingga dapat memacu pertumbuhan tinggi tanaman. Semakin tercukupinya kebutuhan $\mathrm{N}$ yang diberikan maka pertambahan tinggi tanaman juga akan semakin maksimal. Lingga dan Marsono (2004), menyatakan bahwa terjadinya pertumbuhan tinggi dari suatu tanaman disebabkan karena adanya peristiwa pembelahan dan perpanjangan sel yang di dominasi pada ujung pucuk tanaman tersebut. Proses ini merupakan sintesa protein yang diperoleh tanaman dari lingkungan seperti bahan organik dalam tanah. Penambahan bahan organik yang mengandung $\mathrm{N}$ akan mempengaruhi kadar $\mathrm{N}$ total dan membantu sel-sel tanaman dan mempertahankan jalannya proses fotosintesis yang pada akhirnya pertumbuhan tinggi tanaman dapat dipengaruhi. 
Tabel 1. Pengaruh Perlakuan terhadap Tinggi Tanaman Turi.

Waktu

Pengamatan (HST)

\begin{tabular}{cllllll}
\hline \multirow{4}{*}{14} & R0 (Kontrol) & 13,90 & 14,13 & 14,10 & 15,48 & $14,40^{\mathrm{c}}$ \\
& R1 (200g) & 16,24 & 15,86 & 15,44 & 17,38 & $16,23^{\mathrm{bc}}$ \\
& R2 (500g) & 18,26 & 15,88 & 17,76 & 16,96 & $17,22^{\mathrm{b}}$ \\
& R3 (800g) & 22,95 & 21,53 & 23,21 & 19,74 & $21,86^{\mathrm{a}}$ \\
\hline \multirow{3}{*}{21} & R0 (Kontrol) & 16,23 & 17,69 & 16,19 & 16,51 & $16,65^{\mathrm{d}}$ \\
& R1 (200g) & 21,43 & 20,30 & 19,31 & 23,05 & $21,02^{\mathrm{c}}$ \\
& R2 (500g) & 26,01 & 21,08 & 25,75 & 24,08 & $24,23^{\mathrm{b}}$ \\
& R3 (800g) & 32,39 & 29,29 & 33,28 & 29,21 & $31,04^{\mathrm{a}}$ \\
\hline \multirow{3}{*}{28} & R0 (Kontrol) & 18,81 & 21,71 & 20,44 & 20,01 & $20,24^{\mathrm{c}}$ \\
& R1 (200g) & 27,30 & 26,05 & 28,44 & 31,64 & $28,36^{\mathrm{b}}$ \\
& R2 (500g) & 35,70 & 27,76 & 32,64 & 34,18 & $32,57^{\mathrm{b}}$ \\
& R3 (800g) & 42,89 & 36,56 & 47,15 & 42,13 & $42,18^{\mathrm{a}}$ \\
\hline \multirow{3}{*}{35} & R0 (Kontrol) & 22,56 & 26,76 & 24,41 & 25,45 & $24,80^{\mathrm{c}}$ \\
& R1 (200g) & 32,13 & 33,39 & 37,18 & 43,49 & $36,54^{\mathrm{b}}$ \\
& R2 (500g) & 32,13 & 33,39 & 37,18 & 43,55 & $36,56^{\mathrm{b}}$ \\
& R3 (800g) & 55,33 & 52,44 & 63,65 & 57,31 & $57,18^{\mathrm{a}}$ \\
\hline
\end{tabular}

Ket: Angka yang diikuti superscript yang sama menunjukkan berbeda tidak nyata $(P>0,05)$.

\subsection{Pengaruh Perlakuan Terhadap Diameter Batang Tanaman Turi}

Hasil sidik ragam menunjukkan pengaruh nyata antar perlakuan terhadap diameter batang. Tanaman yang diberikan kompos guano $800 \mathrm{~g}$ cenderung meningkatkan diameter batang dibanding tanaman yang diberikan kompos guano 200g, 500g dan kontrol (Tabel 2).

Tabel 2. Pengaruh Perlakuan terhadap Diameter Batang Tanaman Turi

\begin{tabular}{cllllll}
\hline $\begin{array}{c}\text { Waktu } \\
\begin{array}{c}\text { Pengamatan } \\
\text { (HST) }\end{array}\end{array}$ & \multicolumn{5}{c}{ Kompos Guano (g) } & Rerata \\
\hline \multirow{3}{*}{14} & R0 (Kontrol) & 0,30 & 0,33 & 0,34 & 0,31 & $0,32^{\mathrm{c}}$ \\
& R1 (200g) & 0,31 & 0,35 & 0,34 & 0,36 & $0,34^{\mathrm{b}}$ \\
& R2 (500g) & 0,31 & 0,35 & 0,34 & 0,36 & $0,34^{\mathrm{b}}$ \\
& R3 (800g) & 0,39 & 0,43 & 0,45 & 0,44 & $0,43^{\mathrm{a}}$ \\
\hline \multirow{3}{*}{21} & R0 (Kontrol) & 0,31 & 0,33 & 0,34 & 0,31 & $0,32^{\mathrm{c}}$ \\
& R1 (200g) & 0,33 & 0,39 & 0,36 & 0,40 & $0,37^{\mathrm{b}}$ \\
& R2 (500g) & 0,41 & 0,36 & 0,43 & 0,44 & $0,41^{\mathrm{b}}$ \\
& R3 (800g) & 0,49 & 0,48 & 0,55 & 0,49 & $0,50^{\mathrm{a}}$ \\
\hline \multirow{3}{*}{28} & R0 (Kontrol) & 0,35 & 0,38 & 0,35 & 0,34 & $0,35^{\mathrm{d}}$ \\
& R1 (200g) & 0,38 & 0,45 & 0,45 & 0,54 & $0,45^{\mathrm{c}}$ \\
& R2 (500g) & 0,55 & 0,51 & 0,54 & 0,58 & $0,54^{\mathrm{b}}$ \\
& R3 (800g) & 0,65 & 0,61 & 0,78 & 0,66 & $0,68^{\mathrm{a}}$ \\
\hline & R0 (Kontrol) & 0,40 & 0,45 & 0,43 & 0,39 & $0,42^{\mathrm{d}}$ \\
& R1 (200g) & 0,41 & 0,51 & 0,59 & 0,68 & $0,55^{\mathrm{c}}$ \\
& R2 (500g) & 0,68 & 0,60 & 0,69 & 0,68 & $0,66^{\mathrm{b}}$ \\
& R3 (800g) & 0,78 & 0,74 & 0,91 & 0,80 & $0,81^{\mathrm{a}}$ \\
\hline
\end{tabular}

Ket: Angka yang diikuti superskrip yang sama menunjukkan berbeda tidak nyata $(P>0,05)$.

Diameter batang 14 HST, 21 HST, 28 HST dan 35 HST dimana tanah yang diberikan kompos guano $(800 \mathrm{~g})$ cenderung meningkatkan diameter batang $14 \operatorname{HST}(0,43 \mathrm{~cm}), 21 \operatorname{HST}(0,50 \mathrm{~cm}), 28 \operatorname{HST}(0,68 \mathrm{~cm})$ dan 35 HST $(0,81 \mathrm{~cm})$ dibandingkan tanaman turi yang diberikan kompos guano $200 \mathrm{~g}$, $500 \mathrm{~g}$ dan kontrol. Hal ini disebabkan karena kandungan unsur hara yang tersedia pada pupuk kompos guano mampu mencukupi dan dapat memacu diameter batang tanaman turi. Kandungan unsur hara yang tersedia N $(\mathrm{R} 1=451 \%, \mathrm{R} 2=1127,5 \%$ dan R3 $=1804 \%$ ). Perbedaan diameter batang yang dihasilkan antara perlakuan dengan kontrol karena adanya aktivitas pembelahan dan perbesaran sel pada meristem lateral yang mengakibatkan diameter batang menjadi lebih besar. Sesuai dengan pendapat Sarief (2015) yang menyatakan bahwa ketersediaan unsur hara yang dapat diserap oleh tanaman merupakan salah satu faktor yang mempengaruhi pertumbuhan tanaman yang akan menambah pembesaran sel yang berpengaruh pada diameter batang. Unsur hara yang berperan dalam diameter batang adalah unsur $\mathrm{N}$ khususnya pada tanaman yang lebih muda sehingga dengan adanya unsur hara $\mathrm{N}$ dapat mendorong pertumbuhan vegetatif tanaman diantaranya pembentukan klorofil pada daun sehingga akan memacu laju fotosintesis. Semakin cepat laju fotosintesis maka diameter batang tanaman turi akan bertambah.

\subsection{Pengaruh Perlakuan terhadap Jumlah Helai Daun Tanaman Turi}

Hasil sidik ragam menunjukkan pengaruh nyata antar perlakuan terhadap jumlah helai daun. Tanaman yang diberikan kompos guano $800 \mathrm{~g}$ cenderung meningkatkan jumlah helai daun dibanding tanaman yang diberikan kompos guano $200 \mathrm{~g}, 500 \mathrm{~g}$ dan kontrol (Tabel 3).

Jumlah helai daun 14 HST, 21 HST, 28 HST dan 35 HST dimana tanah yang diberikan kompos guano $(800 \mathrm{~g})$ cenderung meningkatkan jumlah daun 14 HST $(7,56), 21 \operatorname{HST}(10,22), 28$ HST $(12,75)$ dan 35 HST $(16,00)$ dibandingkan tanaman turi yang diberikan kompos guano $200 \mathrm{~g}$, 500g dan kontrol. Hal ini disebabkan karena kandungan unsur hara yang tersedia pada pupuk kompos guano mampu mencukupi dan dapat memacu jumlah helai daun tanaman turi. Kandungan unsur hara yang tersedia N (R1 $=451 \%$, R2 $=1127,5 \%$ dan R3= $1804 \%$ ). Pemberian kompos guano dapat meningkatkan ketersediaan unsur hara $\mathrm{N}$ dan K pada tanah sehingga dapat memacu pertumbuhan jumlah tangkai daun. Unsur hara $\mathrm{N}$ dapat memacu pertumbuhan tanaman secara umum, terutama pada fase vegetatif, berperan dalam pembentukan klorofil, asam amino, lemak, enzim, dan persenyawaan lain. Unsur hara $\mathrm{K}$ adalah salah satu unsur kimia yang berperan dalam meningkatkan toleransi terhadap kondisi kering karena mampu mengontrol stomata daun sehingga transpirasi dapat dikendalikan Poerwowidodo (2008). Unsur K berperan dalam membantu pembentukan protein dan karbohidrat, memperkuat tubuh tanaman agar daun, bunga dan buah tidak mudah gugur.

Tabel 3. Pengaruh Perlakuan terhadap Jumlah Helai Daun Tanaman Turi

\begin{tabular}{|c|c|c|c|c|c|c|}
\hline $\begin{array}{c}\text { Waktu } \\
\text { Pengamatan }\end{array}$ & \multicolumn{5}{|c|}{ Kompos Guano (g) } & \multirow{2}{*}{$\frac{\text { Rerata }}{5,56^{\mathrm{c}}}$} \\
\hline \multirow{4}{*}{14} & R0 (Kontrol) & 5,25 & 5,88 & 5,38 & 5,75 & \\
\hline & R1 (200g) & 5,25 & 6,50 & 5,63 & 6,13 & $5,88^{\mathrm{bc}}$ \\
\hline & R2 (500g) & 6,50 & 6,25 & 6,25 & 6,38 & $6,34^{b}$ \\
\hline & R3 (800g) & 6,75 & 7,50 & 8,25 & 7,75 & $7,56^{\mathrm{a}}$ \\
\hline \multirow{4}{*}{21} & R0 (Kontrol) & 6,75 & 7,25 & 6,38 & 7,25 & $6,91^{\mathrm{c}}$ \\
\hline & R1 (200g) & 6,63 & 8,25 & 7,50 & 8,63 & $7,75^{\mathrm{bc}}$ \\
\hline & $\mathrm{R} 2(500 \mathrm{~g})$ & 9,50 & 8,25 & 8,71 & 8,88 & $8,83^{\mathrm{b}}$ \\
\hline & R3 (800g) & 9,38 & 10,00 & 11,25 & 10,25 & $10,22^{\mathrm{a}}$ \\
\hline \multirow{4}{*}{28} & R0 (Kontrol) & 8,38 & 8,63 & 7,50 & 8,75 & $8,31^{\mathrm{c}}$ \\
\hline & $\mathrm{R} 1(200 \mathrm{~g})$ & 8,25 & 10,50 & 8,75 & 11,38 & $9,72^{b c}$ \\
\hline & $\mathrm{R} 2(500 \mathrm{~g})$ & 11,38 & 10,00 & 10,88 & 11,50 & $10,94^{\mathrm{b}}$ \\
\hline & R3 $(800 \mathrm{~g})$ & 12,63 & 12,38 & 13,50 & 12,50 & $12,75^{\mathrm{a}}$ \\
\hline \multirow{4}{*}{35} & R0 (Kontrol) & 11,00 & 11,00 & 10,75 & 11,38 & $11,03^{\mathrm{d}}$ \\
\hline & R1 (200g) & 11,00 & 13,00 & 12,63 & 13,88 & $12,63^{\mathrm{c}}$ \\
\hline & $\mathrm{R} 2(500 \mathrm{~g})$ & 14,63 & 12,63 & 14,13 & 15,50 & $14,22^{\mathrm{b}}$ \\
\hline & R3 (800g) & 15,75 & 15,38 & 16,63 & 16,25 & $16,00^{\mathrm{a}}$ \\
\hline
\end{tabular}

Ket: Angka yang diikuti superscript yang sama menunjukkan berbeda tidak nyata $(P>0,05)$

\section{Simpulan}

Disimpulkan bahwa pemberian pupuk kompos berbahan dasar guano sangat efektif dalam meningkatkan nilai kesuburan tanah sehingga dapat meningkatkan pertumbuhan dan produksi tanaman turi (Sesbania grandiflora) yang terlihat dari tinggi tanaman, diameter batang dan jumlah helai daun.

Pustaka

Lingga, P dan Marsono. 2004. Petunjuk Penggunaan Pupuk. Penebar Swadya. Jakarta.

Murbandono, L.H.S., 2000. Membuat Kompos. Penebar Swadaya, Jakarta.

Poerwowidodo. 2008. Kesuburan dan Pemupukan Tanah Pertanian. Bandung: Pustaka Buana.

Sarief, E.S. 2015. Kesuburan dan Pemupukan Tanah Pertanian. Pustaka Buana Bandung.

Setyorini. D, Saraswati R, Anwar E.K, 2006. Pupuk Organik dan Pupuk Hayati: Kompos http://balittanah.litbang.deptan.go.id/dokumentasi/juknis/ pupuk\% 20 organik.pdf. [diakses tanggal 12 September 2018].

Siregar, S.B. 1994. Ransum Ternak Ruminansia. Penebar Swadaya. Jakarta.

Steel, R.G.D., dan J.H. Torrie. 1995. Prinsip dan Prosedur Statistika suatu Pendekatan Biometrik. Ed ${ }^{2}$ Cet-2 Alih bahasa B. Soemantri. PT. Gramedia Pustaka Utama. Jakarta.

Sutedjo, M.M. 2002. Pupuk dan cara Pembuatan. Rineka Cipta. Jakarta. Susanto, R. 2002. Pertanian organik. Penerbit Kanisius. Yogyakarta. 
J A S 4 (1) 9-11

Journal of Animal Science

International Standard of Serial Number 2502-1869

Widowati, L.R., Sri Widawati, dan W. Hartatik. 2005. Pengaruh Pupuk Organik,

Serapan Hara dan Produksi Sayuran Organik. Tanaman. Balai Penelitian Sayur Lembang. 